\title{
OSMANLI'DA KISA ÖMÜRLÜ BİR HAYIR KURUMU: DULHANE (1884-1896)
}

\begin{abstract}
ÖZ
XIX. yüzyıl Osmanlı devleti için askerî, siyasî, ekonomik ve sosyal açıdan önemli gelişmelerin olduğu bir dönemi ifade eder. XIX. yüzyılın ikinci yarısında Balkanlar'dan ve Kırım'dan gerçekleşmeye başlayan kitlesel göçler bu gelişmelerin en önemlilerinden birisidir. Şehirlere akın eden göçmenler önemli sorunlara yol açmış, devlet bu durum karşısında birtakım tedbirler almak zorunda kalmıştır. Ancak, göçlerin özellikle 1877-1878 Osmanlı-Rus savaşının ardından daha da artarak devam etmesi sorunları içinden çıkılmaz hale getirmiştir. Her ne kadar Osmanlı devleti, gerekli tedbirleri alarak göçmenlerin önemli bir kısmını imparatorluğun çeşitli vilayetlerine yerleştirmişse de, savaşı takip eden yıllarda yine de İstanbul'da büyük sosyal sorunlar ortaya çıkmıştır. İşte bu sorunları çözmek üzere İstanbul'da yeni sosyal yardım kurumları açılmıştır. Bu kurumların en önemlilerinden birisi de Dulhane'dir. Göçmenlere hizmet sunmak üzere Kırmızı Kışla'da faaliyete başlayan kurum, Darülaceze'nin açılmasından bir süre sonra kapatılmıştır. Bu çalışma, ayakta kaldığı kısa sürede önemli hizmetler yerine getiren Dulhane'nin açılmasını, kuruma tahsis edilen gelirleri, sunulan hizmetleri ve bu hizmetlerin değerlendirilmesini amaçlamaktadır.
\end{abstract}

Abdullah BAY"

Anahtar Kelimeler: Dulhane, darülaceze, sosyal yardım, Osmanlı, İstanbul, Eytamhane

\section{A SHORT-LIVED CHARITY IN OTTOMAN: DULHANE}

\begin{abstract}
The $19^{\text {th }}$ century was a period in which there were many significant military, political, economic and social developments in the Ottoman Empire. The mass migrations from the Balkans and Crimea in the second half of the $19^{\text {th }}$ century were among the most important developments of that period. Immigrants who flocked to the cities caused significant problems and therefore the empire had to take some measures against this situation. However, migrations that increasingly continued especially after the Russo-Turkish War (1877-1878) made the problems worse. Although the Ottoman Empire took the necessary measures and enabled most immigrants to settle in various provinces of the empire, in the years following the war, there were still great social problems in Istanbul. In order to solve these problems, new social institutions were established in Istanbul. One of the most important institutions was Dulhane. The institution that started to provide services to immigrants in "Kırmızı Kışla" was closed after "Darülaceze" was established. The present study aims to explain and evaluate the opening of Dulhane, the incomes allocated to the institution, and the services provided.
\end{abstract}

Keywords: Dulhane, darülazece, social aid, Ottoman, Istanbul, Eytamhane

\footnotetext{
* Yrd. Doç. Dr., Recep Tayip Erdoğan Üniversitesi, Fen-Edebiyat Fakültesi Tarih Bölümü, abdullahbay1973@gmail.com
} 


\section{Giriş}

Osmanlı toplumunda sosyal yardım faaliyetlerinin gerçekleştirilmesinde vakıf kurumu etkin bir işleve sahipti. Bütün yardım faaliyetleri din, dil ve etnik köken farkı gözetmeksizin vakıflar eliyle gerçekleştiriliyordu. ${ }^{1}$ XVIII. yüzyıl sonlarında yalnızca İstanbul'daki imarethanelerde her gün 30.000 muhtaç kimseye yemek ikram edilmesi vakıfların ne kadar etkin bir işleve sahip olduğunu kanıtlamaktadır. ${ }^{2}$ Kudüs’teki bir imaretin vakfiyesinde yer alan ".. 'imaret-i 'âmirede beş foduladan dul karıcuklara birer fodula ve birer mikdar çorba verilmek ziyade hayır.." şartı vakıf temelli işleyişe örnek oluşturur. ${ }^{3}$ Gerek devlet adamları ve zenginlerin, gerekse padişahın "atiyye-i seniyye" gibi zaman zaman dul ve fakirlere düzensiz olarak dağıttıkları yardımlar da sistemi tamamlayıcı bir fonksiyona sahipti. ${ }^{4}$ Daha çok yardım esaslı işleyen bu sistem yüzyıllar boyunca sosyal hizmetlerin yerine getirilmesinde en önemli araç olmuştur. Merkezinde vakıf teşkilatının bulunduğu bu klasik sistem, özellikle devletin vakıfların malî kaynaklarına el koyması ${ }^{5}$ ve XIX. yüzyıl boyunca kaybedilen topraklardan gerçekleşen kitlesel göçlerle birlikte hem işlevini önemli oranda yitirmiş, hem de yetersiz kalmaya başlamıştır. Bu gelişmelerle birlikte eskiden beri var olan geleneksel kurumlar yanında modern sosyal hizmet kurumları açılmaya başlanmış, bunun sonucu olarak da sosyal hizmet devletin doğrudan faaliyet ve yetki alanına girmiştir.

\section{Dulhane'nin Açılması ve Faaliyetleri}

Osmanlı devletinde XIX. yüzyılın ikinci yarısında birbiri peşi sıra meydana gelen yenilgiler ve ardından gerçekleşen toprak kayıpları İstanbul ve Anadolu'ya kitlesel göç dalgasına sebep olmuş, bu durum göçmenlerin sayısını giderek artırmıştır. İlk göçmen kafilesi Temmuz 1877'de gelmiş, bunu Ocak 1878'den itibaren günde 10.000 kişiye ulaşan büyük göçmen kitleleri takip etmişti. Yalnızca Temmuz 1877-Eylül 1879 arasında İstanbul'a gelen göçmen sayısı 387.804'e ulaşmıştı. Savaş sonrasında İstanbul'a akın eden binlerce göçmenin arasında bulunan kimsesiz dul kadınlar ile çocukların bakımı önemli bir sorun olarak ortaya çıkmıştır. Özellikle binlerce dul kadın ile anasız babasız yetimlerin barınması ve beslenmesi önemli bir sorun oluşturmaya başlamıştı. ${ }^{6} \mathrm{Bu}$ gelişmeler göçmenlerin ihtiyaçlarını vakıf kurumu aracılığıyla karşılamayı olanaksız kılmıştır.

\footnotetext{
1 Vakıf hizmetleri hakkında geniş bilgi için bkz. Bahaeddin Yediyıldız, "Osmanlılar Döneminde Türk Vakıfları ya da Türk Hayrat Sistemi”, Osmanlı, C.V, (Ed. Güler Eren), Yeni Türkiye Yayınları, Ankara, 1999, s. 17-33; Bahaeddin Yediyıldız, XVIII. Yüzyılda Türkiye’de Vakıf Müessesesi, TTK, Ankara, 2003 , s. 207-235; Bahaeddin Yediyıldız, "Vakıf”, İ , C. XIII, MEB, İstanbul, 1986, s. 153-172.

2 İbrahim Sarıçam, Seyfettin Erşahin, İslam Medeniyet Tarihi, TDV Yayınları, Ankara, 2007, s. 223.

3 BOA, TS.MA.d.(Topkapı Sarayı Müzesi Arşivi Defterleri), 3643, s. 12, 29 Z 963/3 Kasım $1556 .$.

4 BOA, D.BŞM.d.(Bab-l Defteri Başbakıkulu Defterleri), 9059, “..meşâyih fukâralarının ve ba'zl mahallerde sâkin dul hatunların ve fukâra kesân-l sâirinden olan kimselerin defteridir. Yahya Efendi çayırında sâkine Hoca Kadın du'âcıları kuruş 20, Yahya Efendi civârında fukâra-i sâirinden Ademi kadın du 'âclları kuruş.20”. 25 B 1239/26 Mart 1824.

5 Nazif Öztürk, "XIX. Asır Osmanlı Yönetiminde Yaşanan Batılılaşma Hareketlerinin Vakıflar Üzerindeki Etkileri”, İslamî Araştırmalar, C.8, Sayı.1, Kış 1995, s. 13-33.

6 Nuran Yıldırım, “Darülaceze'nin Kuruluş ve İşleyişi””, Toplumsal Tarih, 32/Ağustos 1996, s. 21; Nadir Özbek, Osmanlı İmparatorluğu'nda Sosyal Devlet, İletişim, İstanbul, 2011, s. 199-205; Mustafa Aydın, “1877-1878 Osmanl1-Rus Savaşı Esnasındaki Rumeli Göçünün Meclis-i Mebusan'a Yansımaları ve Yapılan Yardımlar”, Osmanlı Araştırmaları, XLV (2015), s. 209-230.
} 
Hükümet sorunları çözmek üzere ilk adım olarak uzun süre önce kapatılan İdare-i Umumiye-i Muhacirîn Komisyonu'nu yeniden faaliyete geçirerek ${ }^{7}$ göçmenlerin beslenme, barınma, sevk, iskân ve tedavi gibi ihtiyaçlarını organize etme görevini komisyona havale etti. ${ }^{8}$ Göçmenler komisyon denetiminde medreselere, tekkelere, mekteplere, camilere, hanlara, hatta boş saraylara ve konaklara, bunlar da ihtiyaca yeterli gelmeyince evlere yerleştirilmeye başlanmıştı. Bu süreçte Fatih'te birçok boş ve uygun kamu binası dulhane ve eytamhane olarak tahsis edilmiştir. ${ }^{9}$ Üsküdar'da Ahmediye Medresesi Dulhane yapılmış, Mihrimah Sultan ve Şemsi Paşa medreseleri ise göçmenlerin ikametine tahsis edilmişti. Göçmenlere tahsis edilen binalar ihtiyaç azaldıkça boşaltılmıştır. ${ }^{10}$ Hükümet savaşın ardından Bulgar topraklarında kalan yaşlı ve muhtaç kimselere de yardımda bulunmuştur. Muhtar Bulgaristan Prensliği sınırlarında kalan şehir ve kazalarda geçici Dulhaneler açılmış ve bu kurumlara Osmanlı Ticaret vekilleri vasıtasıyla para gönderilmiştir. ${ }^{11}$

İstanbul'a gelen göçmenler hızlı bir şekilde tarımla uğraşabilecekleri vilayetlere sevk edilirken, muhtaç, yaşlı, hasta ve aciz olanların İstanbul'a yerleşmelerine izin veriliyordu. Yine "taşraya sevk olunan muhacirînin öteye beriye nakillerine meydan verilmemesiyle beraber bunlardan vefât edenlerin zevce ve çocuklarl yerlerini burakub dersaâdete gelmekde olduklarından.." kendilerinin meskensiz kalmalarına, devletin ise fazla harcama yapmasına sebep olacağından iskandan sonra taşradan göçe izin verilmemesi ve bulundukları yerlerde bakılmasına özen gösterilmesi için vilayetler sık sık uyarılıyordu. ${ }^{12}$ Göçmenlerin sağlıklı ve sağlam olanlarını İstanbul halkı kısmen evlatlık olarak evlerine almışlarsa da hasta, çalışmaktan aciz, bakacak kimsesi

\footnotetext{
7 Nuran Yıldırım, Ístanbul Darülaceze Müessesesi Tarihi, Darülaceze Vakfı, İstanbul, 1996, s. 8; Rumeli ve Kafkasya'dan yapılan göçler hakkında geniş bilgi için bkz. Nedim İpek, “Kafkaslardan Anadolu’ya Göçler (1877-1900)", Ondokuz Mayls Üniversitesi Eğitim Fakültesi Dergisi, C. 6 (1991), s. 97-133; Nedim İpek, Rumeli'den Anadolu'ya Türk Göçleri, TTK, Ankara, 1999, s. 58-68; Mehmet Demirtaş, "Kırım Savaş1 ve 93 Harbi Sürecinde Osmanlı Memleketine Gelen Göçmenlerin Sevk ve İskânları", Atatürk Üniversitesi Türkiyat Araştırmaları Enstitüsü Dergisi, 41, Erzurum, 2009, s. 215-238.

8 Osman Nuri Ergin, Mecelle-i Umûr-l Belediyye, 6, İstanbul Büyükşehir Belediyesi Kültür İşleri Daire Başkanlı̆̆1 Yayınları, İstanbul, 1995, s. 3469-3472.

9 BOA, Y.PRK.KOM.(Yıldız Perakende Evrakı Komisyonlar Maruzatı), 4/8, 21 Ca 1300/30 Mart 1883.

${ }^{10}$ BOA, DH.MKT.(Dahiliye Nezareti Mektubi Kalemi Evrakl), 1343/105, Dahiliye Nezaretinden Şehremanetine tezkere, 15 R 1301/12 Şubat 1884.

11 "Filibe'de Dulhâne ve medreselerde iskân ve ikâme edilmiş olan Muhacirîne verilmek üzere ...yüz lira bu kere nezâret veznedârına tevdi 'an irsâl kılınmağla..”, BOA, DH.MKT., 1801/41, Dahiliye Nezaretinden Bank-1 Osmani Müdürlüğüne tezkere, 8 Ks 1306/20 Ocak 1891; Daha sonra dokuz yüz otuz sekiz frank gönderilmiştir. BOA, DH.MKT., 1820/25, Dahiliye Nezaretinden Sadarete tahrir, 2 Mart 1307/14 Mart 1891. ${ }^{12}$ BOA, DH.MKT., 2057/44, Dahiliye Nezaretinden Göçmen İskan olunan vilayetlere tezkere, (Edirne, Hüdavendigar, Aydın, Konya, Adana, Haleb, Suriye, Kastamonu, Sivas, Ankara, Diyarbekir, Mamûreti'laziz, Şehremenaneti, Trabzon, Selanik, Kosova, Erzurum, Manastır, Çatalca, Beyrut, İşkodra, İzmir) 6 Ks 1308/18 Ocak 1893; “..kâr u kisbden 'aciz oldukları bi'l-etraf tahkîk olunarak içlerinde zıra 'ât ve hırâsete elverişli bulunanların taşralarca arazi-i kâffeye i'tâ olunmak üzere münâsib mahallere Zabtiye nezareti vasitasılla sevki ve zıra 'ât ve hırâset edecek kimsesi bulunmaması hasebiyle burada iskân ve i'âşesi zaruri olan dul kadınlar...", BOA, BEO.(Babıali Evrak Odası Evrakı), Sadaretten Dahiliye Nezaretine tezkere, 24 M 1310/17 Ağustos 1892; Diğer bir belgede gerekçe şu şekilde zikredilmiştir. “...daha vâsi ' mahalleriyle kifâyet etmeyeceğinden bu misillulerin imrarlarına müsa 'âde ve ăgmaz edenlerin mes'ûl edileceklerine ve kurrâ ve mahallât-ı eimmesinin bunlar için ilmühaber vermemeleri..”, BOA, DH.MKT., 10 N 1310/28 Mart 1893.
} 
bulunmayan, sakat ve iş göremeyecek derecede yaşlı olanlar ortada kalmıştı. ${ }^{13}$ Özellikle dul ve yetimlerin korunması için devlet tarafindan yeni kurumlar oluşturulması ihtiyacı artık görünür hale gelmişti.

Hükümet, sorunu çözmek üzere kışla olarak kullanılan Gülhane'deki Kırmızı Kışla’yı geçici süreliğine göçmenlere tahsis ederek Dulhane adıyla bir kurum açmış ve idaresini Muhacirîn Komisyonu'na vermiştir. ${ }^{14}$ Dulhane'ye tahsis edilen Kırmızı Kışla bir yapılar topluluğundan oluşuyordu. Kırmızı Kışla "etraf-l erba 'ası duvarlı kâgir ve üç katdan ibaret bulunan ebniye-i cesîme ahşab klsmi yani tavan ve döşeme ve sakfi alt katında çamaşuy haneden karantina ittihaz kılınan koğuş..." tan ibaretti. ${ }^{15}$ Hizmet birimleri Muhacirîn Hastanesi, Eytamhâne, Dulhane ve Eytâm-1 Muhacirîn Mektebinden oluşuyordu. ${ }^{16}$ Devletin kuruma ayırdığg tahsisat kurumun ana gelir kaynağını oluşturuyordu. Bunun yanında "te'sisi mukarrer olan Dârülâceze'nin inşasıyla küşâdına kadar resmen bir komisyon teşkiliyle i 'anât-l 'umûmiyeye müraca 'ât ve bu cümleden olmak ve bir def'âya mahsûs bulunmak üzere me'murîn maaşından dahi yüzde bir iki nisbetinde bir şey tevkif olunarak bundan hâsıl olacak mebâliğ ile o misillulerin muvakkaten iskân ve i âşeleri.." sağlanıordu. ${ }^{17}$

Dulhane'nin açılış tarihi kesin olarak belli değildir. Kurum hakkındaki en eski belge 10 Şaban 1302/4 Haziran 1884 tarihlidir. Belgede anasız, babasız ve muhtaç durumda bulunan göçmen çocukların sünnet ettirilmeleri ve mektepte eğitim gören öğrencilerin sınavlarının yapılması isteniyordu. ${ }^{18}$ Ayrıntılı bilginin yer almadığ bu belgeden Dulhane'nin en azından bu yıl faaliyette bulunduğunu öğrenmekteyiz. Dulhane'nin mevcudu hakkında bilgi veren en eski belge ise 15 Teşrin-i Sani 1302/27 Kasım 1886 tarihlidir. ${ }^{19}$

Dulhane kapsam ve tür olarak ilk defa devlet tarafından açılmış ve hizmete geçirilmiş kurumlardan biridir. Ancak, uzun süreli bir kurum olarak planlanmadığ 1 anlaşılmaktadır. Bunun da en önemli sebebi kuruma tahsis edilen Kırmızı Kışla'nın onarıma muhtaç bir durumda bulunmasıdır. ${ }^{20} \mathrm{Bu}$ sebeple açılmasından kısa süre sonra Dulhane'de barınan yetişkinlerin açılacak yeni hastanelere, çocukların ise mekteplere aktarılması gündeme getirilmiş, ancak bu kararın Dahiliye Nezareti tezkeresiyle sadrazamlığa ulaştırılması üzerine Meclis-i Mahsus'ta alınan karar doğrultusunda yetişkinlerin “...ekserisi alîl ve müsinn oldukları mülâbesesiyle bunların hizmetçilikde

\footnotetext{
13 İstanbul Ansiklopedisi, 8, (Ed. Reşad Ekrem Koçu), Hamle ve Sıralar Matbaası, İstanbul, 1966, s.42424245 .

${ }_{14}$ BOA, BEO., 704/52773, Sadaretten Dahiliye Nezaretine tezkere, 28 Ca 1312/26 Kasım 1894.

${ }^{15}$ BOA, I.HUS.(Írade Hususi), 27/58, Muhacirîn Komisyonundan Şehremanetine tezkere, 29 Haziran 1310/11 Temmuz 1894.

16 Yildirim, a.g.e., s.8.

${ }^{17}$ BOA, DH.MKT., 1892/53, Dahiliye Nezaretinden Muhacirîn Komisyonuna tezkere, 9 Ts 1307/21 Kasım 1891.

${ }_{18}$ BOA, Y.MTV.(Yıldız Mütenevvi Maruzat Evrakı), 18/9, 10 Ş 1302/4 Haziran 1884.

19 Jurnale göre bu sırada Eytamhane'de 91 erkek, 40 kız, Dulhane'de 185 yaşlı, 2 küçük, Eytâm-1 Muhacirîn Mektebi'nde ise 91 erkek, 40 kız olmak üzere toplam 318 kişi barınıyordu. BOA, Y.PRK.KOM., 4/96, Eytamhâne ile Dulhane ve Eytam-1 Muhacirîn mektebinin yevmî mevcûdunu nâtık jurnaldir., 15 Ts 1032/27 Kasim 1886.

20 “..Gülhânede vâki “ muhacirîne mahsûs Dulhâne ve hastahanelerin müşrifü’l-harâb olduğu ve bunların elli altı bin kuruşla ta 'miri müte 'ahhidi 'uhdesinde takarrür eylediği...", BOA, DH.MKT., 1523/86, Dahiliye Nezaretinden Maliye Nezaretine Tezkere, 29 Haziran 1304/11 Temmuz 1888.
} 
kullanılmaları kâbil olamadı̆̆ misillu hastanelerin nisâ ve gurebâ hastahânelerinde tedavisine kendilerinin husûl-ı muvaffakiyetleri mümkün.." görülmediğinden eskiden olduğu gibi aynı yerde kalmalarına karar verilmiştir. ${ }^{21}$

Dulhane'nin yönetimine ilişkin esaslı düzenleme yapılmamıştır. Ancak, önemli bir görevli kadrosunun bulunmasından düzenli bir işleyişinin olduğu anlaşılmaktadır. Genel olarak göçmenlerin kuruma sevkleri İdare-i Umumiye-i Muhacirîn Komisyonu için hazırlanan "Dersaâdet Muhacirîn İdaresi Hakkında Talimat"a göre yapılmıştır. ${ }^{22}$

Kuruma önemli sayıda idareci ve memur atanmıştır. Dulhane'nin başında temel yürütme organı olarak müdür bulunmaktadır. 1888 yılında Dulhane müdürlügünde Fehim Bey bulunuyordu. Bu yıl içinde yapttğı hizmetlerden dolayı rütbe ile ödüllendirilmiştir. ${ }^{23}$ Mevcut bir belgeden kurumu idare etmek üzere bir azalık tesis edildiği anlaşılmaktadır. 16 Zilkade 1309/ 11 Haziran 1892‘de Ali Nafiz Bey fahri heyet azası olarak atanmıştı. ${ }^{24}$ Yine Dulhane idaresi azasından Mazhar Efendi hizmetlerinden dolayı rütbe-i saniye ile ödüllendirilmiştir. ${ }^{25} \mathrm{Bu}$ sırada Mehmed Ali Efendi depo memurluğu görevinde bulunuyordu. ${ }^{26}$ Bundan yaklaşık üç yıl sonra Dulhane hastanesi müdürü Mehmed Emin Efendi, kâtibi ise Abdullah Efendi idi. ${ }^{27}$ Mektebin muallim-i sanisi Mehmed Efendi idi. Bu sırada kurumda görevli memur ve idarecilerin bazılarının isimlerine ulaşılabilmektedir. Bu tarihte Dulhane ve Eytamhane müdürü Mehmed Mazhar Efendi, muavini ise Mehmed Efendi idi. Başlıca hastane görevlileri ise hastalar ağası, depo memuru, kapu çukadarı, kapııı, hastahane tımarcısı, serhademe, aşçı, meydancı, kilerci ve vekilharç idi. ${ }^{28}$

Dulhane, hizmet birimlerinden de anlaşıldığı gibi yalnızca yaşlı ve dullara hizmet etmekle kalmamış, aynı zamanda hastalara ve çocuklara da barınma, korunma ve sağlık hizmetleri sunmuştur. Kuruma gelen dul kadınlar ve yetim çocuklar Muhacirîn Dul ve Eytamhanesi'ne yerleştiriliyor, hastalar ise yine buradaki Muhacirîn Hastanesi'nde tedavi altına alınıyordu. ${ }^{29}$ Ayrıca, aynı süreçte Anadolu'nun bazı önemli şehirlerinde İstanbul'daki örneğe uygun Dulhaneler açılmıştır. ${ }^{30}$ Anadolu ve Rumeli kazalarından

\footnotetext{
${ }^{21}$ BOA, A.MKT.MHM.(Sadaret Mektubi Mühimme Kalemi Evrakı), 492/57, 14 S 1304 tarihli meclis-i Mahsus Mazbatas1, Dahiliye Nezaretine Cevab-1 Sâmi, 19 S 1304/15 Kasım 1886; BOA, MF.MKT.(Maarif Nezareti Mektubi Kalemi Deavi Evrakı), 163/41, 9 Şubat 1308/21 Şubat 1893.

${ }^{22}$ Süleyman Erkan, Kırım Kafkasya ve Doğu Anadolu Göçleri (1878-1908), Karadeniz Teknik Üniversitesi Kafkasya ve Orta Asya Uygulama ve Araştırma Merkezi, Trabzon 1996, s.98-107.

${ }_{23}$ BOA, DH.MKT., 1511/39, Dahiliye Nezaretinden Sadarete Tezkere, 25 N 1305/5 Haziran 1888; Fehim Bey yaptığı hizmetler karşılığı Şura-yı Devlet Dahliye dairesi muavinliğine terfi ettirilmiş, burada Dulhane müdürlüğü sırasında kalan yaşlıları karşılıksız çalıştırdığı iddiasıyla kurumda kalan yaşlılar tarafından verilen arzuhaller sebebiyle yargılanmıştır. “...Dulhâne müdürlüğünde bulunduğu esnada muhacir kadınların ba'zllarına işlettirdiği işlerin ücretini vermediğine ve bu ise me'mûriyetini suiistimal demek olduğuna....". BOA, Şura-yı Devletten Muhacirîn Komisyonuna mazbata, 18 B 1306/20 Mart 1889.

${ }^{24}$ BOA, DH.MKT., 1959/97, 16 Za 1309/; BOA, İ.TAL.(İrade Taltifat), 4/1310, 24 S 1310/16 Eylül 1892.

${ }_{25}$ BOA, DH.MKT., 2059/85, Dahiliye Nezaretinden Muhacirîn Komisyonuna tezkere, 19 Ş 1310/8 Mart 1893.

${ }^{26}$ BOA, DH.MKT., 1883/70, Dahiliye Nezaretinden Muhacirin Komisyonuna tezkere, 25 R 1309/27 Kasim 1891.

27 BOA, DH.MKT., 385/1, Şehremanetinden Dahiliye Nezaretine tezkere, 5 Z 1312/30 Mayıs 1895.

${ }_{28}$ BOA, ŞD.(Şura-yı Devlet Evrakı), 2673/8, Müstahdem olunanlar pusulas1, 20 C 1314/26 Kasım 1896.

${ }_{29}$ Yıldırım, a.g.e., s. 8.; "Darülaceze", İstanbul Ansiklopedisi, 8, s. 4242-4245.

30 “..bunun mahalline iâdesi bütün bütün sefâlet ve perişaniyetini mucib olacağl cihetle kendüsünün Dulhâneye kabulü ve bundan böyle bu misillu erâmil ve eytâmın dersaâdete gönderilmeyub mahallerince
} 
Dulhane'ye gönderilen muhtaçların "ilânihâye yersiz ve mekânsız kalmalarını ve imtidad-ı sefâletlerini bâis olacă̆l cihetle. mahallerince hüsn-i muhafaza ve idare.." edilmeleri gerektiği belirtiliyordu. ${ }^{31}$

Dulhane'ye kabulde en temel şart başvuranın göçmen olması, bunun yanında kocası, bakacak erkek çocuğu ve meskeninin bulunmamasıydı. Bu şart özellikle Balkanlardan yapılan kitlesel göçlerle yakından alakalıdır. Örneğin, "bundan bir mah mukaddem şeref-i İslâm olduğundan ve bîkes ve bîmekân bulunduğundan bahisle Dulhânede iskân ve i'âşesini müsted 'î mühtediye Zeliha hatun"un arzuhali kuruma yerleştirilmesine gerekçe olmuştur. ${ }^{32}$ Kuruma "muhacirînden hanesi olubda evlâdzükûr veya zevci olmayan kadın" göçmenler yerleştiriliyor, ancak göçmen olmayıp zor durumda kalan yaşlıların geçici süreliğine barınmasına izin veriliyordu. ${ }^{33}$ Örneğin, Şefika göçmen olmamasına rağmen "bîkes ve bîvâyeliğinden ve han köşelerinde

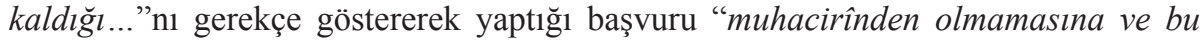
makûlelerin Dulhâneye kabulü halinde mevcûdun tekessür ve idarenin kesb-i müşkilât eylemesi melhûz bulunmasına binâen..." ${ }^{34}$ geçici olarak kabul edilmiştir. ${ }^{35}$ Göçmen olmayan yaşlılar ise gelen göçmenlere devamlı yer açabilmek amacıyla Acezehane'ye yönlendiriliyordu ${ }^{36}$. Başvurular Dulhane ve Muhacirîn Komisyonu başta olmak üzere, Dâhiliye Nezareti ve Sadarete yapılıyordu. Yapılan başvurular soruşturularak bilgilerin doğruluğu araştırılıyor, göçmen olmayanlar mecbur kalmadıkça kuruma

hüsn-i muhafaza ve idareleri...”, BOA, DH.MKT., 1723/77, Dahiliye Nezaretinden Muhacirîn Komisyonuna Tezkere, 22 N 1307/11 Mayıs 1890; “...Zevcesi Hanife Hatun ile iki nefer çocuğunu bilânafaka İzmir Dulhânesinde terk eylediği..”, BOA, HR.SFR.04.(Hariciye Nezareti Paris Sefareti), 582/85, Sadrazamlıktan Vidin Ticaret Vekaletine, 13 Mayıs 1307/25 May1s 1891.

31 BOA, DH.MKT., 1723/61, Dahiliye Nezaretinden Muhacirîn Komisyonu ve Vilayetlere tezkere, 18 Mart 1306/30 Mart 1890.

32 BOA, DH.MKT., 1662/17, Dahiliye Nezaretinden Şehremanetine Tezkere, 18 Eylül 1305/30 Eylül 1889.

33 “..Tirnova muhacirlerinden olub fâkire ve bîkes olmakla beraber Çatalcada mesken ve me’vası dahi olmayan Aişe hatunun beş yaşında bir çocuğuyla beraber emsâli vecihle Dulhânede i âşe etdirilmek üzere gönderildiği...", BOA, DH.MKT., 1432/40, Dahiliye Nezaretinden Erbaa Mutasarrıflı̆̆ına Tezkere, 1 Temmuz 1303/13 Temmuz 1887; “..Dersaâdete gelmiş ve kimsesizliği cihetle hâl-i sefalet ve perişaniyetde kalmış olduğundan bahisle işlerinin tesviyesine kadar Dulhânede ikâmesi istirhamına ...icabının ifâsına..", BOA, DH.MKT., Dahiliye Nezaretinden Şehremanetine Tezkere, 30 Ağustos 1304/11 Ağustos 1888; "..Vidin muhacirlerinden Aişe imzasıyla taraf-ı sâmi-i sadâretpenâhiye takdîm ve i tâ ve leffen isrâ kılınan 'arzuhalde bîkes olub bir nefer kerîmesiyle meydanda kaldı̆̆ından bahisle muhafazası zımnında Dulhânede istihdamı...", BOA, DH.MKT., 1521/61, Dahiliye Nezaretinden Muhacirin Komisyonuna Tezkere, 28 Mart 1304/9 Nisan 1888; “..Sofya muhacirlerinden Şeref hatun bîkes ve bîvâyeliğinden nâş̧i Dulhâneye kabulü istid 'â olunmuş...", BOA, DH.MKT., 1613/33, Dahiliye Nezaretinden Muhacirin Komisyonuna Tezkere, 18 Mart 1305/30 Mart 1889; "..fakîr halinden bahisle mahdûmiyle beraber Dulhâneye kayd ve kabulü..”, BOA, DH.MKT., 209/17, Dahiliye Nezaretinden Muhacirin Komisyonuna Tezkere, 6 Ra 1309/10 Ekim 1891.

${ }^{34}$ BOA, DH.MKT., 1701/29, Dahiliye Nezaretinden Şehremanetine Tezkere, 30 Ks 1305/11 Şubat 1890; “..zevcinin vukû'-l vefatı cihetle üç nefer çocuğuyla sokak ortasında kaldıklarından bahisle Dulhâneye kabulleri istid 'asını hâvi Emine imzasıyla huzur-ı âli-i sadâretpenâhiye bi 't-takdîm..", BOA, DH.MKT., 125/16, Dahiliye Nezaretinden Muhacirîn Komisyonuna tezkere, 21 S 1311/2 Eylül 1893.

${ }^{35}$ BOA, DH.MKT., 1693/57, Dahiliye Nezaretinden Muhacirin Komisyonuna Tezkere, 16 Ks 1305/28 Ocak 1890.

36 “Şefika Hatunun bîkes ve bîvâye ve mekânsızlı̆̆ından bahisle Dulhâneye gönderilmesi hakkında vâki 'olan istid 'âsı üzerine mezbûre sûret-i muvakkatadan Dulhâneye kabul edilmiş ise de muhacirîn olmamasına... emanetçe maaş tahsisi kâbil olamayacağından yalnız emanete merbût olan Acezehâneye kabul ile i'âşe olunmalarına...", BOA, DH.MKT., 1819/135, Dahiliye Nezaretinden Şehremanetine tezkere, 4 Mart 1307/16 Mart 1891; Daha önce açılan Acezehane hakkında geniş bilgi için bkz. Yıldırım, a.g.m., s. 16-29. 
alınmıyordu. İstanbul ahalisinden yetim çocuklar ve dul kadınların başvuruları Şehremanetine havale ediliyordu. ${ }^{37}$ Mahalle sakinlerinin başvurusu üzerine de kabuller gerçekleştirilebiliyordu. ${ }^{38}$ Muhtacîn maaşı alanların maaşları kuruma kabul edildiklerinde kesiliyordu. ${ }^{39}$ Bebekli dul kadınların kurumda kalmasına izin verilmesine karşın yetişkin çocuklar ya yatılı mekteplere, ya da Darüşşafaka'ya gönderiliyordu. ${ }^{40}$ Kuruma kabul edilen yetişkin çocuklar suç işlemeleri durumunda kurumdan çıkarılabiliyordu. ${ }^{41}$

Dulhane çatısı altında kalan kimsesiz ve muhtaç çocuklara sunulan diğer bir önemli hizmet, okuma çağına gelen çocuklara temel eğitimin verilmesidir. Bu amaçla kurum bünyesinde bir mektep açılmıştır. Mektepte temel dinî ve genel bilgiler veriliyor, ağırlıklı olarak meslek eğitimi öncelikli bir müfredat uygulanıyordu. İbtidaî mektepte temel eğitimi alan çocukların uygulamalı eğitimleri Tersane ve Tophane'de bulunan sıbyan sanayi taburlarında gerçekleştiriliyordu. ${ }^{42}$

Dulhane'ye kabul edilenlerden çalışabilecek durumda olan kadınlar zaman zaman evlere hizmetçi olarak gönderiliyordu. Ocak 1895 'de 10 kişi evlerde hizmetçilik yapmaktayd $1 .{ }^{43}$ Bakacak akrabası olanlar veya iskân edilmek isteyenlerin kurumdan ayrılmalarına izin veriliyordu. Mart 1895' de kurumda kalan birinin isteği üzerine "mahallatda bulunan kerimeleri nezdine" çıkmasına izin verilmişti. ${ }^{44}$ Diğer

\footnotetext{
37 “..ahali-i kadîm fukarâsının te'min-i i'âşe ve muhafazaları şehremanet-i celîlesine 'aid idiğünden ..emanet-i müşârünileyhaca bir mahal bulunarak te 'min-i esbâb-ı i 'âşe ve muhafazaları lâzım geleceği ...', BOA, DH.MKT., 1892/53, Tarihsiz; ".şayan-ı merhamet bir halde bulunduğundan bahisle oğluyla beraber Dulhâneye kayd olunması Silistre muhacirlerinden Aişe imzasılyla verilen arzuhalde istid 'â olunmuş...", BOA, DH.MKT., 2012/23, Dahiliye Nezaretinden Muhacirîn Komisyonuna Tezkere, 1 Ta 1308/13 Ekim 1892; “..şimdiye değin hizmetçilik ile ma işsetini te'min etmekde iken ma 'lûle olduğundan ve barınacak bir mekânı bulunmadığından isti 'tafi hâvi Şumnu muhacirlerinden Atiyye imzasıyla..”, BOA, DH.MKT., 138/13, Dahiliye Nezaretinden Muhacirîn Komisyonuna tezkere, 11 Ş 1309/10 Mart 1892; BOA, DH.MKT., 244/23, Dahiliye Nezaretinden Muhacirîn Kmsiyonuna tezkere, 17 Mayıs 1310/29 Mayıs 1894; Bazı dul kadınlara yalnızca erzak yardımı da yapılıyordu. BOA, BEO., 1209/90638, Sadaretten Dahiliye Nezaretine tezkere, 24 Ca 1316/10 Ekim 1898.

38 BOA, DH.MKT., 1753/23, Dahiliye Nezaretinden Muhacirîn Komisyonuna tezkere, 8 Ağustos 1306/20 Ağustos 1890; Göçmen olmadığ halde muhtaç bir kadının misafireten kalmasına izin verilmiştir. BOA, DH.MKT., 1892/53, 19 R 1309/21 Kasım 1891; BOA, DH.MKT., 1961/35, Dahiliye Nezaretinden Muhacirîn Komisyonuna Tezkere, 2 Haziran 1308/14 Haziran 1892; BOA, DH.MKT., 1961/82, Dahiliye Nezaretinden Muhacirîn Komisyonuna Tezkere, 2 Haziran 1308/14 Haziran 1892; ".fâkir halinden ve bîmekân bulunduğundan bahisle..”, BOA, DH.MKT., 1973/118, Dahiliye Nezaretinden Muhacirîn Komisyonuna Tezkere, 7 Temmuz 1308/19 Temmuz 1892.

39 “..muhtacîn maaşının karşılığı kalmamış olduğundan merkûm Osmana dahi maaş bìt-tahsî̀ kâbil olamayacăgl..”, BOA, DH.MKT., 1710/48, Dahiliye Nezaretinden Muhacirîn Komisyonuna tezkere, Gurre Ş 1307/22 Mart 1890.

40 BOA, DH.MKT., 1860/105, Dahiliye Nezaretinden Muhacirîn Komisyonu ve Darüşşafaka Müdürlügüne tezkere, 4 Ağustos 1307/16 Ağustos 1891.

41 “iki nefer çocuğuyla Dulhâne'de ikâmet etmekte iken mahdûmu Kamili etmiş olduğu vuk̂े'-ı kabahatinden dolayı ihrâç edildiklerinden..", BOA, DH.MKT., 235/35, Dahiliye Nezaretinden Muhacirîn Komisyonuna tezkere, 28 Ş 1310/17 Mart 1893.

42 BOA, A.MKT.MHM., 492/57, 14 Safer 1304 tarihli meclis-i Mahsus Mazbatası, Dahiliye Nezaretine Cevab-1 Sami, 19 S 1304/15 Kasım 1886; BOA, MF.MKT., 163/41, 9 Şubat 1308/21 Şubat 1893.

${ }^{43}$ BOA, Y.PRK.MŞ.(Yıldız Perakende Evrakı Meşihat Dairesi Maruzatı), 6/33, 27 B 1313/12 Ocak 1896; BOA, YK.PRK.KOM., 8/64, 2 Ş 1312/28 Ocak 1895.

${ }^{44}$ BOA, Y.PRK.KOM., 8/69, 23 N 1312/20 Mart 1895.
} 
bir kadın kocası yanına, bir diğeri ise iskân edilmek üzere taşraya gönderilmişti. ${ }^{45}$ Kurumda kalan göçmenlerin taşraya veya İstanbul'da akrabaları yanına misafir olarak gitmelerine de izin veriliyordu. Yine aynı tarihte 17 kişinin misafirliğe çıktığ görülmektedir. ${ }^{46}$

Sağlık hizmetleri Dulhane sakinlerine sunulan önemli hizmetlerden birisidir. $\mathrm{Bu}$ amaçla kurumda bir hastane açılmıştı. Hastane aracılığıyla gerek kurumda kalanlara, gerekse Muhacirîn Komisyonu'nun sevk ettiği göçmenlere eczane ve poliklinik hizmetleri sunuluyordu. Özellikle kış mevsiminde mevsimsel şartlara bağlı olarak hastaneye başvurularda artış gözlenmektedir. Örneğin, 26 Kanun-1 Evvel 1310/7 Ocak $1895^{\prime}$ de hastaneye 26 kişi başvurmuştu. ${ }^{47}$

Dulhane açık kaldığı kısa süre içinde önemli sayıda yaşlı ve çocuğun barınma mekânı olmuştur. 1886'dan kurumun kapatılarak kalanların Darülaceze'ye devredildiği 1895 'e kadar Dulhane, Eytamhane ve Eytam-1 Muhacirîn mektebi mevcutlarına düzenli olarak ulaşılabilmektedir. Bu verilere göre savaşın ardından kurum önemli sayıda göçmene ev sahipliği yapmıştır. Kurum en yüksek mevcuduna 329 kişiyle 5 Aralık 1891 tarihinde ulaşmıştır. Kurumda kış aylarında gerçekleşen düşüşler, hastalıklar ve misafirliğe çıkışlarla ilgili olmalıdır. 31 Ocak 1895'de kurumda kalan sayısı 172'ye düşerek en düşük sayıya inmiştir. ${ }^{48}$

Kurumda zaman zaman yönetim, fizikî ortam ve sağlikla ilgili birtakım sorunlar yaşanmıştır. ${ }^{49}$ Örneğin, Batum göçmeni Fatma sekiz yıl kaldığı kurumdan geçimsizliği sebebiyle çıkarılarak Bursa'ya gönderilmiş, geri alınması için yaptığ başvuru ise şartlı olarak kabul edilmiştir. ${ }^{50}$ Diğer sorunlar daha çok yönetim ve sağlıkla ilgilidir. Örneğin kurumun kolera kaynağı olduğu hazırlanan raporlara yansımıştır. Yine 27 Ş 1309/26 Mart 1892'de kurumda bulunan çocuklar çiçek salgınına maruz kalmışlard1. ${ }^{51}$ Kuruma tahsis edilen binadan kaynaklanan olumsuz fizikî şartlar yanında kurumun varlığının hukukî zemine oturtulamaması, kapatılmasına neden olan en önemli sorunlardı.

\section{Mekân Sorunu: Dulhane'nin Kapatılması}

Göçmenlerin barınma ihtiyaçları için açılan ve açık kaldığı kısa sürede önemli hizmetler yerine getiren kurum fizikî yapıya yönelik önemli sorunlarla karşılaşmıştır. Dulhane'nin fizikî şartlarıyla ilgili en önemli sorunu kurumun çok eski bir hizmet binasına sahip olmasıdır. Bunun için de belgelere sık sık onarım girişimleri yansımıştır. Aralık 1891'de Dulhane'ye tahsis edilen Kırmızı Kışla'nın yıkılmaya yüz tutması sebebiyle onarım kararı alınmış, bu sırada kurumda barınan çocukların Dikimhane'ye nakli planlanmıştır. Karar doğrultusunda Şehremaneti tarafından yapılan keşif sonucu

${ }^{45}$ BOA, Y.PRK.KOM., 4/96, 3 Ra 1304/29 Kasim 1886; BOA, Y.PRK.KOM., 4/106, 23 C 1304/18 Mart 1887.

${ }^{46}$ BOA, Y.PRK.MŞ., 2/22, 21 Za 1305/30 Temmuz 1888.

${ }^{47}$ BOA, Y.PRK.MŞ., 6/33, 27 B 1313/12 Ocak 1896; BOA, YK.PRK.KOM., 8/64, 2 Ş 1312/28 Ocak 1895.

48 Ayrıntılı bilgi için Tablo.1'e bkz.

${ }^{49}$ Görevliler ile Batumlu bir göçmen kadın arasında çıkan kavga için bkz. BOA, DH.MKT., 240/9, Dahiliye Nezaretinden Muhacirîn Komisyonuna tezkere, 18 Za 1311/24 Mayıs 1894.

${ }^{50}$ BOA, DH.MKT., 192/30, Muhacirîn Komisyonundan Dahiliye Nezaretine tezkere, 5 B 1311/12 Ocak 1894.

${ }^{51}$ BOA, DH.MKT., 1937/3, 27 Ş 1309/26 Mart 1892. 
yüksek bir onarım bedeli gerektiği anlaşılınca, bütçe kısıtlaması sebebiyle onarımından vaz geçilmiştir. ${ }^{52}$

Bundan sonra da tamiratıyla ilgili yazışmalar devam etmiştir. ${ }^{53}$ Özellikle öncelikli tehlike arz eden binanın çatısında bazı küçük onarımlar yapılmıştır. Buna karşın Eytamhane'nin çatısının tehlike arz etmeye devam ettiğ $i^{54}$ ve bir an önce onarılması gerektiği bildirilmiştir. ${ }^{55}$ Nezaretler arası yazışmalar sonucu Meclis-i Vükela'da durum görüşülmüş, esaslı bir çözüm düşünülmek üzere Seraskerlik inşaat dairesine keşfi yaptırılmış ve 215.779 Kuruş tutan onarım masrafının 1894 bütçesine konulması kararlaştırılmıştır. ${ }^{56} \mathrm{Bu}$ sırada kurumda kalanların sağlıkları düşünülerek suyolları tamir ettirilmiştir. ${ }^{57}$

1894 yılında meydana gelen depremde Dulhane olarak kullanılan Kirmızı Kışla'nın ciddî şekilde zarar görmesi üzerine uzun süre ertelenen onarımdan vaz geçilmiştir. Depremin ardından keşif yapmak üzere görevlendirilen Şehremaneti mühendisleri Tevfik Bey, Rıza Efendi ve Kosti Kalfa hazırladıkları raporda duvarlarında ve özellikle de ahşap çatısında çatlaklar oluştuğundan binanın tahliye edilmesini tavsiye etmişlerdir. ${ }^{58}$ İstanbul' da Ağustos 1893 'te başlayan ve Nisan 1894'te söndürülen kolera salgını sebebiyle Münih Üniversitesi'nden Alman doktor Prof. Rudolf Emmerich'e de binanın sağlık durumu hakkında keşif yaptırılmıştır. Dr. Emmerich raporunda kurumun

\footnotetext{
52 BOA, DH.MKT., 1902/57, Dahiliye Nezaretinden Seraskerlik makamına tezkere, 14 Ca 1309/16 Aralık 1891; “..seraskerî ile cereyan eden muhabere cevâbında mezkûr Kırmızı Kışla civârında mekteb-i Tıbbiye tes sisi ve inşası hakkındaki tasavvurdan mu'ahharan sarf-ı nazar olunmasına mebni zikr olunan Kırmızı Kışla'nın mübadelesine mahall kalmamış...", BOA, DH.MKT., 1909/21, Dahiliye Nezaretinden Muhacirîn Komisyonuna tezkere, 7 Ca 1309/9 Aralık 1891; BOA, DH.MKT., 214/16030, Sadaretten Dahiliye Nezaretine tezkere, 24 May1s 1309/5 Haziran 1893; BOA, DH.MKT., 2056/79, Dahiliye Nezaretinden Sadarete tezkere, 15 Ş 1308/26 Mart 1891.

53 BOA, DH.MKT., 2021/55, Dahiliye Nezaretinden Maliye Nezaretine tezkere, 28 Ta 1308/9 Kasim 1892; BOA, BEO., 281/21063, Sadaretten Dahiliye Nezaretine tezkere, 14 Ra 1311/24 Eylül 1893.

54 “...ansızın inhidamı halinde bir fâci'a-i elîme vuku'-l melhûz bulunduğundan bahisle bir tehlike baş göstermeden serî' 'an icrâ-yı ta 'miratı lüzûmunu mutazammın Muhacirîn komisyonu riyâset-i celîlesinden vârid...", BOA, BEO., 162/1209, Sadaretten Şehremanetine tezkere, 16 Şubat 1308/28 Şubat 1893; "Dulhâne ittihaz olunan Kırmızı Kışla nam mahallin dahi masârif-i keşfiyesi olan yüz elli iki bin yedi yüz doksan dokuz kuruş altı paradan boya vesâire gibi termîmatdan add edilmeyen on bir bin dört yüz kırk dört kuruş otuz beş para bi 't-tenzîl mütebaki yüz kırk bir bin üç yüz elli dört kuruş on bir paranın sarfiyla melhûz olan tehlikelerinin ref'î kâbil olub..", BOA, BEO., 173/2902, Muhacirîn Komisyonundan Dahiliye Nezaretine tezkere, 8 Ş 1310/25 Şubat 1893.

55 "..depo ittihaz olunan mahallin sakfi bu def"a def"aten yıkldiğı ve bir takım eytâm ve erâmilin beytûtet etmekde oldukları binaların da tehlike ve muhatara içinde bulunduğu..", BOA, DH.MKT., 2050/13, Dahiliye Nezaretinden Maliye Nezaretine tezkere, 24 Ks 1308/5 Şubat 1893; “..derûnunda üçyüzü mütecaviz erâmil ve eytâm ikâmet etmekde bulunan Kırmızı Kışlanın dahi inhidamı halinde böyle bir fâci 'a-i elîme vukî 'u aşikâr olarak bu kadar nüfûsun hayatı hal-i tehlikede olduğu..”, BOA, BEO., 173/2902, Muhacirîn Komisyonundan Dahiliye Nezaretine tezkere, 8 Ş 1310/25 Şubat 1893.

${ }_{56}$ BOA, BEO., 173/2902, Sadaretten Dahiliye ve Seraskerliğe tezkere, 2 Mart 1309/14 Mart 1893; BOA, BEO., 214/16030, Sadaretten Dahiliye Nezaretine tezkere, 24 May1s 1309/5 Haziran 1893; BOA, I.DH. (İrade Dahiliye), 1307/28, Meclis-i Vükelâ kararı, 22 S 1311/3 Eylül 1893.

${ }^{57}$ BOA, Y.MTV., 79/207, Dahiliye Nezaretinden Hazine-i Hassa Nezaretine tezkere, 28 Z 1310/12 Temmuz 1893; BOA, DH.MKT., 85/18, Muhacirîn Komisyonundan Dahiliye Nezaretine tezkere, 14 Z 1310/28 Haziran 1893.

${ }^{58}$ BOA, I.HUS., 27/58, Muhacirîn Komisyonundan Şehremanetine tezkere, 29 Haziran 1310/11 Temmuz 1894.
} 
kolera kaynağ1 olduğunu belirtmiştir. ${ }^{59} \mathrm{Bu}$ olumsuz raporlara rağmen hükümet onarım için yeni bir girişimde bulunmuştur. Onarım çalışmaları sırasında kalanların kurulacak barakalara veya yakınında kiralanacak yerlere taşınması planlanmıştır. ${ }^{60}$ Onarım masrafını karşılamak üzere bankadan avans akçesi temin edilmiş; ancak kış mevsiminin gelmesi sebebiyle biraz daha beklenilmesine karar verilmiştir ${ }^{61}$. Fakat daha sonra yapılan değerlendirme ile onarımdan vaz geçilmiş, kurumun "hareket- $i$ arzdan rahnedâr olmasindan sarf-l nazarla dul ve yetim ve hastalarin mahall-i ma 'lûmeye yerleşdirilmesi ve mezkûr kışlanın 'akîb-i tahliyede tathirât-ı fenniye icrâ kllınarak devletçe tensîb kılınacak mahalle ..." taşınması kararlaştırılmıştır. ${ }^{62}$ Kurumun kapatılmasında en önemli sebeplerden birisi de "Rusya ve Rumeli'den gelen muhacirîn aktarma sûretiyle vilayât-l münasibeye sevk ve i'zam kılındıklarl cihetle ba'dezin gelecek muhacirler vapurlarda doğrudan doğruya vilayât-ı münasibeye sevk ve i zam kllınacaklarl cihetle dul ve Eytamhâneye gideceklerin arkast.."nın kesilmesidir. ${ }^{63}$ Muhacirîn hastahane ve Dulhanesi 274.801 Kuruşa ulaşan 1895 y1lı bütçesiyle birlikte önce Şehremanetine devredilmiş, ${ }^{64}$ daha sonra ise binası Seraskerliğe iade edilmiştir. ${ }^{65}$

Dulhane' de barınan hasta kadın ve çocuklar Haseki Nisa, Gureba ve Şehremaneti hastanelerine, erkek çocuklar Tophane ve Tersane-i Amire sanayi alaylarına, kız çocuklar akşam kız sanayi mektebine, yetim erkek çocuklar ise Darüşşafaka ve akşam askerî idadisine yerleştirilmiş ve $1311 / 1895$ 'de Darülaceze açılınca kadınlar ve çocuklar Haseki' den alınarak buraya nakledilmişlerdir. ${ }^{66} 22$ Receb 1314/27 Aralık 1896 tarihli belgede naklin tamamlandığ 1 tespit edilmektedir. ${ }^{67}$

Kurumun kapatılmasından sonra hastahanede görevli doktor ve eczacılar eski görev yerlerine, memurlar ise geçici olarak Nisa hastanesi çalışanlarının görev yaptığ 1 Darülaceze'ye aktarılmıştır. Bir kısım memurun ise başlangıçta bir süre açığa alınarak

\footnotetext{
${ }^{59}$ BOA, DH.MKT., 368/71, Meclisi-i Vükelâ mazbatası, 26 Z 1312/20 Haziran 1895.

${ }^{60}$ BOA, I.HUS., 27/58, Muhacirîn Komisyonundan Şehremanetine tezkere, 29 Haziran 1310/11 Temmuz 1894 ve Padişah iradesi, 20 Haziran 1310/2 Temmuz 1894.

${ }^{61}$ BOA, DH.MKT., 302/11, 5 Ca 1312/3 Kasim 1894; BOA, BEO., 509/38162, Dahiliye Nezaretinden Sadarete tezkere, Selh R 1312/29 Ekim 1894.

${ }^{62}$ BOA, BEO., 697/52252, Sadaretten Seraskerliğe tezkere, 5 Ca 1313/23 Ekim 1895; BOA, DH.MKT., 368/71, Meclis-i Vükelâ mazbatası, 26 Z 1312/20 Haziran 1895.

${ }_{63}$ BOA, DH.MKT., 368/71, Meclisi-i Vükelâ mazbatası, 26 Z 1312/20 Haziran 1895.

${ }^{64}$ BOA, BEO., 557/41747, Şehremanetinden Sadarete tezkere, 20 B 1312/16 Ocak 1895; "Dul ve eytâmhâne idaresinin Dârülâcezeye nakli hasebiyle memurîn-i maâşatıyla masârif-i seneviyyesi olarak Defter-i Hakâni nezâret-i celîlesinden muhavvel mebâliğin dahi Dârülâceze varidâtı meyânına idhâli..", BOA, BEO., 833/2410, Sadaretten Dahiliye Nezaretine Tezkere, 14 Ra 1314/23 Ağustos 1896; Kurum kapatıldıktan sonra çalışanlarının maaş sorunları uzun süre devam etmiştir. BOA, BEO., 512/38382, Sadaretten Dahiliye Nezaretine, 27 Ta 1311/8 Kasım 1895; BOA, BEO., 559/41896, Sadaretten Şehremanetine tezkere, 20 N 1312/17 Mart 1895; “..Mülgâ Muhacirîn Komisyonu Dulhâne ve hastahânesi kabileliğinden açıkda kaldığından bahisle..”, BOA, DH.MKT., 2091/17, Dahiliye Nezaretinden Umum Mekatib-i Askeriyeye tezkere, 26 Ra 1314/4 Eylül 1896; BOA, ŞD., 2983/78, Şehremanetinden Şura-y1 Devlete tezkere, 22 Ta 1312/4 Aralık 1896; BOA, DH.MKT., 368/71, Dahiliye Nezaretinden sadarete tezkere, 16 Nisan 1311/28 Nisan 1895; BOA, BEO., 704/52773, Şehremanetinden Dahiliye Nezaretine tezkere, 17 R 1313/6 Ekim 1895; BOA, BEO., 647/48520, Sadaretten Bahriye Nezareti, Tophane Müşirliği, Mekatib-i Askeriye ve Maarif Nezaretine Tezkere, 2 M 1313/25 Haziran 1895.

${ }^{65}$ BOA, DH.MKT., 368/71, Meclisi-i Vükelâ mazbatas1, 26 Z 1312/20 Haziran 1895.

${ }^{66}$ BOA, DH.MKT., 368/71, Meclis-i Vükelâ mazbatas1, 26 Z 1312/20 Haziran 1895; Ístanbul Ansiklopedisi, 8, s.4242-4243; Hidayet Y. Nuhoğlu, "Dârülâceze", DİA, 8, İstanbul 1993, s. 513-515.

${ }^{67}$ BOA, BEO., 833/2410, Sadaretten Dahiliye Nezaretine tezkere, 22 B 1314/27 Aralık 1896.
} 
daha sonra ihtiyaç çıktıkça farklı kurumlarda görevlendirilmesine karar verilmiştir. ${ }^{68}$ $\mathrm{Bu}$ karar doğrultusunda 18 kişi dişında bütün kurum çalışanları Darülaceze'ye aktarılmıştır. ${ }^{9}$ Memuriyet dışında kalan "...on altı neferin on neferi mezkûr idare ve hastahane müdür ve katib ve depoy memuru ve kapu çukadarl ve kilerci ve vekilharç ve hademe gibi hizmetlerde ve diğer altı neferi mekteb muallimi ve kapucu ve tımarc ve aşçı ve meydancı namiyla ahiren müstahdem...hademe-i mûmaileyhimden eciren müstahdem olanlardan mekteb mualliminin maârif nezâret-i celîlesince ve diğer beş neferinin dahi devâir-i belediyece tanzifât vesâir münasib hizmetlerde ve diğer on neferin de tekâüd sandıkından istifade edemeyecekleri anlaşıldı̆̆ $ı$ cihetle hidemât-ı münasibe-i mülkiyede istihdam.. " edilmelerine karar verilmiştir. ${ }^{70}$

Dulhane'nin hizmet süresi kısa olsa da etkisinin kalıcı olduğu anlaşılmaktadır. Darülaceze Nizamnamesi'nin hazırlanmasında burada elde edilen tecrübenin önemli katkısı olmuştur. Dulhane'nin kapatılmasından sonra vilayetlerde bu örneğe uygun bazı kurumların açıldığı tespit edilmektedir. Örneğin, "Cezâyir-i Bahr-i Sefid vilâyetinde bulunan Girid muhacirlerinden dul ve şayân-l merhamet olanlarının topluca bir mahalde bulunmaları zımnında Rodosda inşa kılındı̆̆ı gibi.." Aydın vilayetinde de bir dulhane açılmıştır. ${ }^{71}$ Dulhane ve onun hemen peşinden açılan Darülaceze daha sonra gerçekleşen kurumsallaşmaya örnek oluşturmuştur. ${ }^{72}$

\section{Sonuç}

Osmanlı klasik sosyal yardım kurumlarının merkezinde özerk bir yapıya sahip vakıf kurumu yer alıyordu. Vakıflar, muhtaçlara aylık bağlanması, yetim çocukların giydirilmesi ve beslenmesi, dulların evlendirilmesi gibi çeşitli sosyal yardım faaliyetlerini yerine getiriyorlardı. XIX. yüzyılda Osmanlı devletinin sahip olduğu topraklarının büyük bir bölümünü kaybetmesi sonucu ortaya çıkan kitlesel göçler vakıf temelli sosyal hizmet yapısını değişime uğratmıştır. Şehirlere akın eden göçmenler, barınma ve beslenme sorunlarına yol açmasının yanında dilencilik, hırsızlık ve gasp gibi asayiş sorunlarını da artırmıştır. Bu durum devletin tedbir almasını zorunlu hale getirmiştir. Devlet soruna çözüm bulmak amacıyla kurumsallaşmaya hız vermek zorunda kalmıştır. $\mathrm{Bu}$ kurumsallaşma döneminde açılan kurumlardan birisi de Dulhane'dir.

Öncelikli olarak muhtaç göçmenlere barınma imkânı sunmak amacıyla açılan Dulhane’ye Kırmızı Kışla tahsis edilmiş ve bütün masrafları devlet tarafından karşılanmıştır. Kısa hizmet süresi boyunca önemli hizmetleri yerine getiren kurum, fizikî şartlarının kötü olmasından dolayı çeşitli zorluklar yaşamıştır. Kurum ve bağlı organları yine bu sebepten dolayı kısa süre sonra kapatılmak zorunda kalınmıştır. Dulhane'nin kapatılmasından sonra burada kalan kimseler, başta Darülaceze olmak üzere çeşitli kurumlara dağıtılmışlardır. Kurumda görev yapan idareci ve memurların

\footnotetext{
${ }^{68}$ BOA, DH.MKT., 368/71, Dahiliye nezaretinden Şehremanetine tezkere, 18 Haziran 1311/30 Haziran 1895; BOA, BEO., 833/2410, Sadaretten Dahiliye Nezaretine tezkere, 22 B 1314/27 Aralık 1896.

${ }_{69}$ Darülaceze hakkında geniş bilgi için bkz. Özbek, a.g.e., s.200-215; Ergin, a.g.e., 6, s .3470-3472.

70 BOA, ŞD., 2673/8, Müstahdem olunanlar pusulas1, 20 C 1314/26 Kasım 1896.

71 BOA, DH.MKT., 2902/94, Dahiliye Nezaretinden Aydın Vilayetine tezkere, 29 B 1327/16 Ağustos 1909 72 "..merkez ve mülhakâtda darüleytâm ve dulhâne ve tedavihâne ve darülmesâi müessesat tesis edilmiş...", BOA, DH.I.UM.EK.(Dahiliye Nezareti İdare-i Umumiye Evrakl), 104/106, Dahiliye Nezareti tezkeresi, Ka 1332/Aralık 1916; Darülaceze'nin faaliyetleri hakkında bkz. Yıldırım, a.g.e., s. 162-200.
} 
çoğunluğu önemli sayıda elemana ihtiyaç duyan Darülaceze'ye kaydırılmış, geri kalan az sayıdaki görevliler ise diğer devlet kurumlarında görevlendirilmiştir. XIX. yüzyılın son çeyreğinde olağanüstü şartlarda kurumsal temelli yatılı bakım hizmetleri sunan Dulhane ve büyük oranda bu tecrübeden yararlanılarak açılan Darülaceze daha sonraki sosyal hizmet kurumlarının temelini oluşturmuştur.

\section{KAYNAKÇA}

AYDIN, Mustafa, “1877-1878 Osmanl1-Rus Savaşı Esnasındaki Rumeli Göçünün Meclis-i Mebusan'a Yansımaları ve Yapılan Yardımlar”, Osmanlı Araştırmaları, XLV(2015), s. 209-230.

"Darülaceze", İstanbul Ansiklopedisi, 8, (Ed. Reşad Ekrem Koçu), Hamle ve Sıralar Matbaas1, İstanbul, 1966, s. 4242-4245.

DEMİRTAŞ, Mehmet, "Kırım Savaşı ve 93 Harbi Sürecinde Osmanlı Memleketine Gelen Göçmenlerin Sevk ve İskânları”, Atatürk Üniversitesi Türkiyat Araştırmaları Enstitüsü Dergisi, 41, Erzurum, 2009, s.215-238.

ERGİN, Osman Nuri, Mecelle-i Umûr-ı Belediyye, 6, İstanbul Büyükşehir Belediyesi Kültür İşleri Daire Başkanlığı Yayınları, İstanbul, 1995.

ERKAN, Süleyman, Kırım Kafkasya ve Doğu Anadolu Göçleri (1878-1908), Karadeniz Teknik Üniversitesi Kafkasya ve Orta Asya Ülkeleri Uygulama ve Araştırma Merkezi, Trabzon 1996.

İPEK, Nedim, "Kafkaslardan Anadolu'ya Göçler (1877-1900)", Ondokuzmayıs Üniversitesi Ë̆itim Fakültesi Dergisi, C. 6 (1991), s. 97-133.

Rumeli'den Anadolu'ya Türk Göçleri, TTK, Ankara, 1999.

NUHOĞLU, Hidayet Y., "Dârülâceze", DİA, 8, İstanbul, 1993, s. 513-515.

ÖZBEK, Nadir, Osmanlı Imparatorluğu’nda Sosyal Devlet, İletişim, İstanbul, 2011.

ÖZTÜRK, Nazif, "XIX. Asır Osmanlı Yönetiminde Yaşanan Batılılaşma Hareketlerinin Vakıflar Üzerindeki Etkileri”, İslamî Araştırmalar, C.8, Sayı.1, Kış 1995, s. 1333.

SARIÇAM, İbrahim, Erşahin, SEYFETTİN, İslam Medeniyet Tarihi, TDV Yayınları, Ankara, 2007.

YEDIYILDIZ, Bahaeddin, XVIII. Yüzyılda Türkiye'de VakıfMüessesesi, TTK, Ankara, 2003.

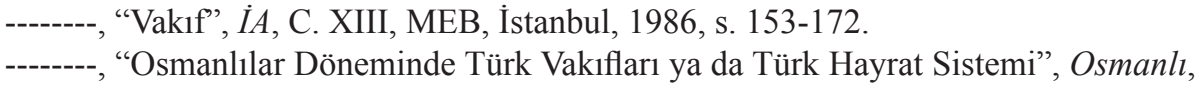

C. V, (Ed. Güler Eren), Yeni Türkiye Yayınları, Ankara, 1999, s. 17-33.

YILDIRIM, Nuran, İstanbul Darülaceze Müessesesi Tarihi, Darülaceze Vakfi, İstanbul, 1996.

,"Darülaceze'nin Kuruluş ve İşleyişi”, Toplumsal Tarih, 32/Ağustos 1996, s. 16-29. 


\section{Arşiv Kaynakları}

\section{BOA (Başbakanlık Osmanlı Arşivi)}

-A.MKT.MHM. (Sadaret Mektubi Mühimme Kalemi Evrak1), 492/57.

-BEO. (Babiali Evrak Odası Evrak1), 1209/90638; 162/1209; 173/2902; 173/2902; 214/16030; 281/21063; 323/24156; 509/38162; 512/38382; 557/41747; 559/41896; 647/48520; 697/52252; 704/52773; 833/2410.

-D.BŞM.d. (Bab-1 Defteri Başbakıkulu Defterleri), 9059.

-DH.İ.UM.EK. (Dahiliye Nezareti İdare-i Umumiye Evrak1), 104/106.

-DH.MKT. (Dahiliye Nezareti Mektubi Kalemi Evrak1), 125/16; 1343/105; 138/13; $1432 / 40 ; 1511 / 39 ; 1521 / 61 ; 1523 / 86 ; 1613 / 33 ; 1662 / 17 ; 1701 / 29 ; 1710 / 48$; $1723 / 77 ; 1753 / 23 ; 1801 / 41 ; 1819 / 135 ; 1820 / 25 ; 1883 / 70 ; 1892 / 53 ; 1902 / 57$; $1909 / 21 ; 192 / 30 ; 1937 / 3 ; 1959 / 97 ; 1961 / 35 ; 1961 / 82 ; 1973 / 118 ; 1995 / 53$; 2012/23; 2039/48; 2048/87; 2056/79; 2057/44; 2059/85; 2091/17; 214/16030; $235 / 35 ; 240 / 9 ; 244 / 23 ; 2902 / 94 ; 302 / 11 ; 368 / 71 ; 385 / 1 ; 85 / 18 ; 1723 / 61$; 2021/55; 2050/13.

-HR.SFR.04. (Hariciye Nezareti Paris Sefareti), 582/85.

-İ.DH. (İrade Dahiliye), 1307/28.

-İ.HUS. (İrade Hususi), 27/58.

-İ.TAL. (İrade Taltif), 4/1310.

-MF.MKT. (Maarif Nezareti Mektubi Kalemi Deavi Evrak1), 163/41.

-ŞD. (Şura-yı Devlet Evrak1), 2673/8; 2983/78.

-TS.MA.d. (Topkapı Sarayı Müzesi Arşivi Defterleri), 3643.

-Y.MTV. (Yıldız Mütenevvi Maruzat Evrakı), 18/9; 79/207.

-Y.PRK.DH. (Y1ldız Perakende Evrakı Dâhiliye Nezareti Maruzat1), 3/8.

-Y.PRK.KOM. (Yıldız Perakende Evrakı Komisyonlar Maruzat1), 4/106; 4/8; 4/96; 8/69; 8/64; 4/94; 4/96; 4/111; 8/71; 8/58; 8/56; 8/64.

-Y.PRK.MF. (Yıldız Perakende Evrakı Müteferrik), 3/19; 1/51; 1/56.

-Y.PRK.MŞ.(Yıldız Perakende Evrakı Meşihat Dairesi Maruzatı), 2/22; 6/33; 2/27; $2 / 60 ; 2 / 88 ; 3 / 35 ; 3 / 47 ; 3 / 19 ; 4 / 26 ; 2 / 11$. 
Tablo 1. Dulhane, Eytamhane ve Eytam-1 Muhacirin Mektebi mevcudu

\begin{tabular}{|l|c|c|c|c|c|c|c|}
\hline \multicolumn{1}{|c|}{ Ay-Yıl } & \multicolumn{2}{|c|}{ Eytamhane } & \multicolumn{2}{c|}{ Dulhane } & \multicolumn{2}{c|}{ Mektep } & Toplam \\
\hline & Erkek & Kadın & Büyük & Küçük & Erkek & Kız & \\
\hline 27 Kasım 1886 & 91 & 40 & 185 & 2 & 91 & 40 & 318 \\
\hline 30 Kasım 1886 & 92 & 40 & 186 & 3 & 92 & 40 & 321 \\
\hline 25 Aralık1886 & 76 & 25 & 162 & 1 & 76 & 25 & 264 \\
\hline 2 Şubat 1887 & 91 & 42 & 184 & 2 & 91 & 42 & 312 \\
\hline 17 Mart 1887 & 84 & 42 & 181 & 2 & 84 & 42 & 309 \\
\hline 26 Mart 1887 & 85 & 42 & 176 & 1 & 85 & 42 & 304 \\
\hline 30 Nisan 1887 & 80 & 41 & 173 & 1 & 80 & 41 & 295 \\
\hline 10 Aralık 1887 & 83 & 30 & 177 & 1 & 82 & 30 & 290 \\
\hline 30 Temmuz 1888 & 82 & 25 & 169 & 1 & 82 & 25 & 277 \\
\hline 3 Ekim 1888 & 76 & 25 & 162 & 1 & 76 & 25 & 264 \\
\hline 15 Kasım 1889 & 88 & 44 & 106 & 1 & 88 & 44 & 239 \\
\hline 5 Aralık 1889 & 88 & 44 & 106 & 1 & 88 & 44 & 239 \\
\hline 1 Ağustos 1890 & 78 & 25 & 112 & 1 & 78 & 25 & 226 \\
\hline 1 Eylül 1890 & 78 & 25 & 112 & 1 & 78 & 25 & 226 \\
\hline 2 Ağustos 1891 & 88 & 20 & 154 & 1 & 88 & 30 & 273 \\
\hline 5 Aralık 1891 & 88 & 30 & 160 & 1 & 118 & 88 & 329 \\
\hline 15 Aralık 1893 & 85 & 4 & 157 & & 85 & 4 & 246 \\
\hline 20 Mart 1894 & 68 & 0 & 161 & 0 & 68 & 0 & 228 \\
\hline 14 Nisan 1894 & 85 & 4 & 157 & 0 & 85 & 4 & 246 \\
\hline 9 Ağustos 1894 & 61 & 4 & 142 & 0 & 61 & 4 & 208 \\
\hline 11 Ekim 1894 & 21 & 4 & 145 & 0 & 61 & 4 & 210 \\
\hline 29 Kasım 1894 & 67 & 0 & 164 & 0 & 67 & 0 & 178 \\
\hline 22 Aralık 1894 & 67 & 0 & 161 & 0 & 67 & 0 & 181 \\
\hline 6 Ocak 1895 & 67 & 4 & 151 & 0 & 67 & 4 & 222 \\
\hline 31 Ocak 1895 & 67 & 0 & 106 & 0 & 67 & 0 & 172 \\
\hline 20 Mart 1895 & 68 & 0 & 160 & 0 & 68 & 0 & 228 \\
\hline 7 Nisan 1895 & 68 & 68 & 158 & 0 & 68 & 68 & 227 \\
\hline
\end{tabular}

Kaynak: Y.PRK.KOM., 4/94; Y.PRK.MF., 3/19; Y.PRK.KOM., 4/96; Y.PRK. DH.(Yıldız Perakende Evrakı Dahiliye Nezareti Maruzatı), 3/8; Y.PRK.KOM., 4/106; Y.PRK.MF.(Yıldız Perakende Evrakı Müteferrika), 1/51; Y.PRK.KOM., 4/111; Y.PRK. KOM., 4/106; Y.PRK.MF., 1/56; Y.PRK.MŞ., 2/22; Y.PRK.MŞ., 2/27; Y.PRK.MŞ., 2/60; Y.PRK.MŞ., 2/88; Y.PRK.MŞ., 3/35; Y.PRK.MŞ., 3/47; Y.PRK.KOM., 8/71; Y.PRK. KOM., 8/58; Y.PRK.MSS., 3/19; Y.PRK.KOM., 8/56; Y.PRK.KOM., 8/64; Y.PRK.MŞ., 6/33; Y.PRK.KOM., 8/69; Y.PRK.MŞ., 4/26; Y.PRK.MŞ., 2/60; Y.PRK.MŞ., 2/11; Y.PRK.KOM., 8/58; Y.PRK.KOM., 8/64. 


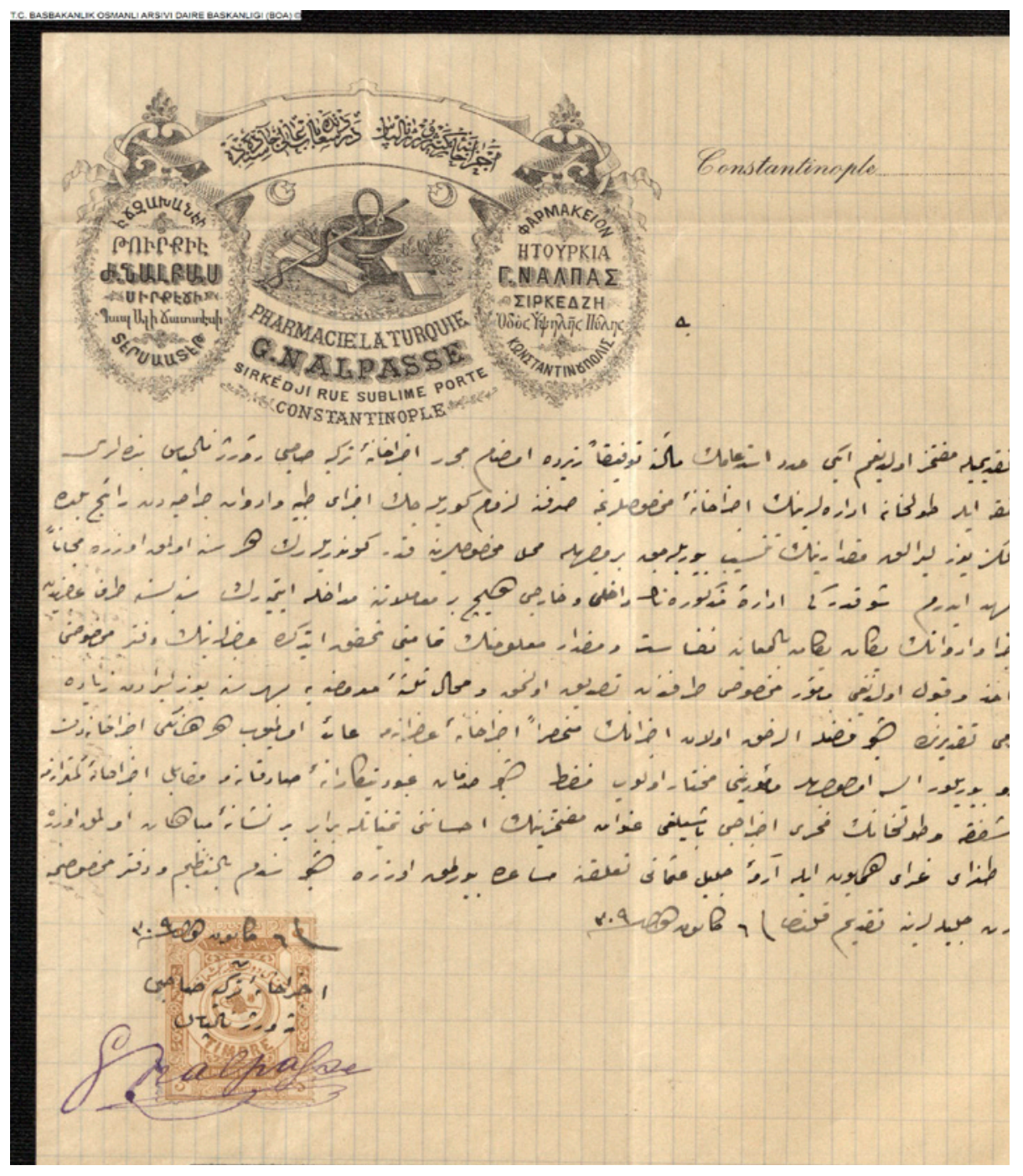

Belge 1. Türkiye Eczanesi sahibi Corc Nalpas Efendi'nin Dulhane'ye ilaç yardımı (BOA, BEO., 323/24156). 


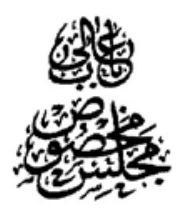

เาช

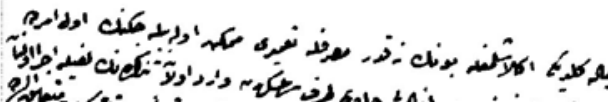

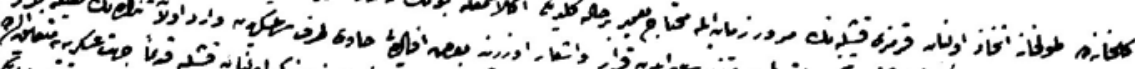

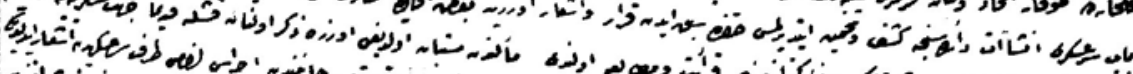

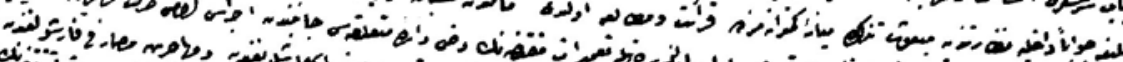

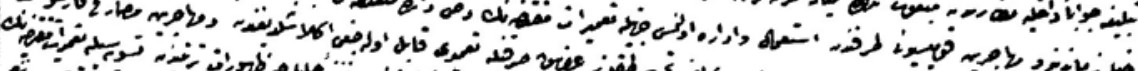

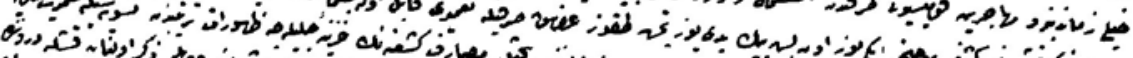

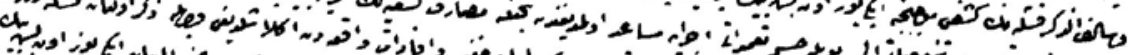

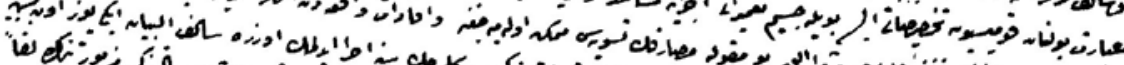

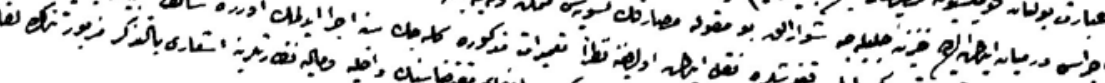

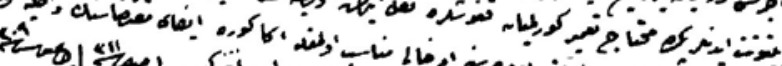

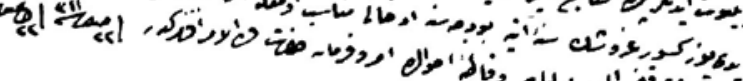

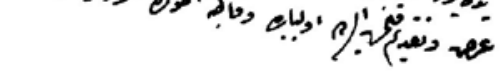

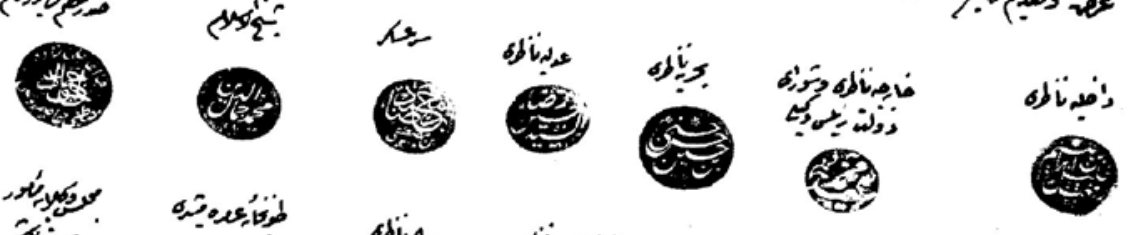
קون: ;3).
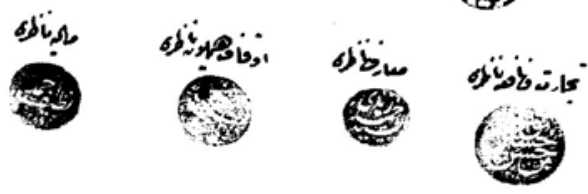

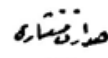
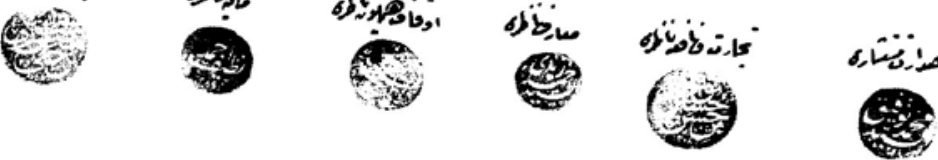

Belge 2. Dulhane'nin onarımı ile ilgili meclis-i vükela kararı (BOA, İ.DH., 1307/49). 


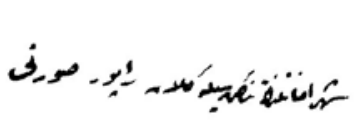

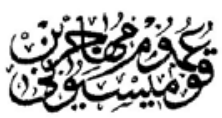

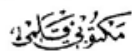

$\Delta \sqrt{2}$

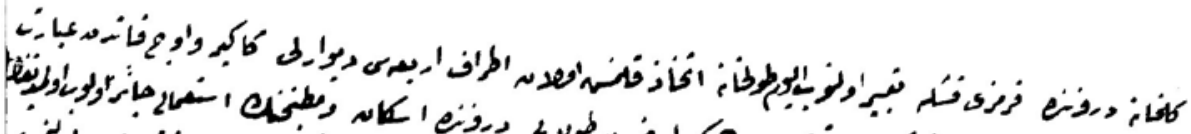

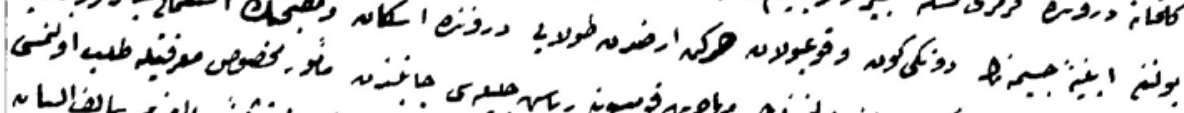

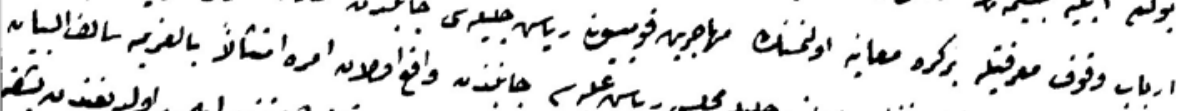

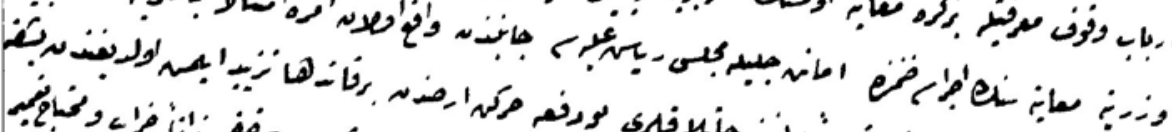

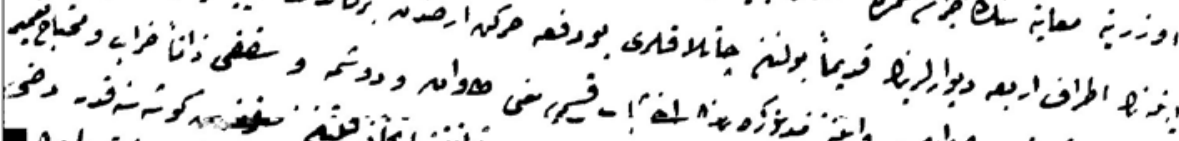

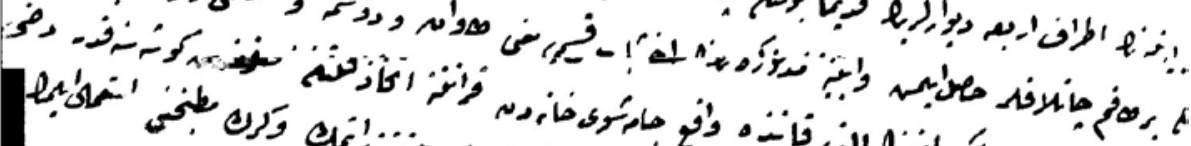

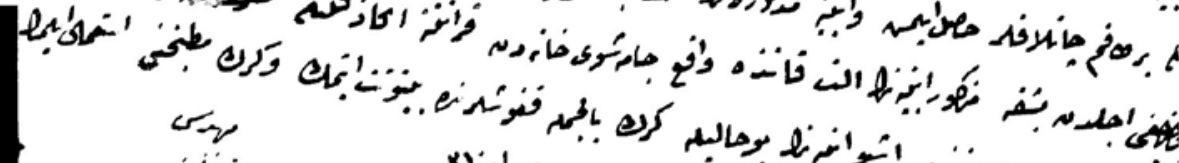

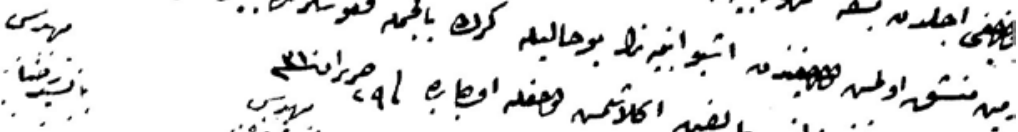

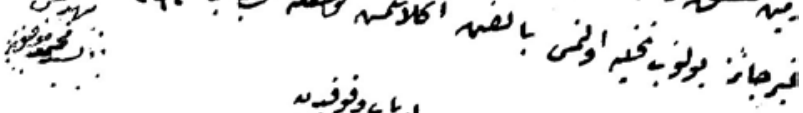

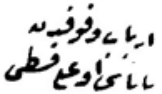

مالمه

Belge 3. Depremin Dulhane'ye verdiği zarar hakkında rapor (BOA, İ.HUS., 27/58). 


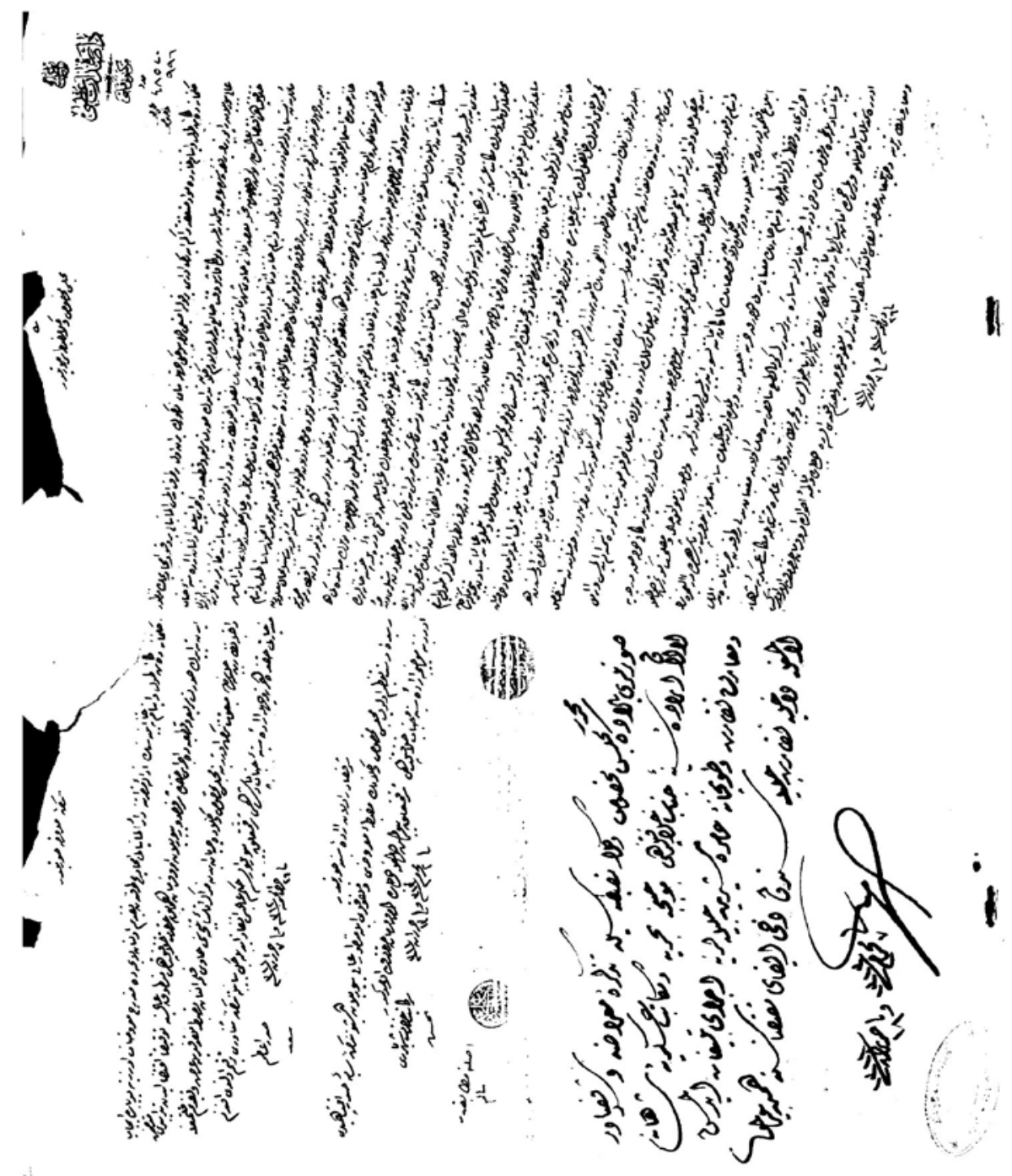

Belge 4. Dulhane'nin kapatılmasına dair Meclis-i vükela mazbatası (BOA, DH.MKT., 368/71). 